\title{
Severe Human Metapneumovirus Pneumonia in a Healthy Obese Child
}

\author{
Sağlıklı Obez Bir Çocukta İnsan Metapnömovirüs İlişkili \\ Ciddi Seyirli Pnömoni
}

\author{
Gülhadiye Avcu', Nurşen Belet' ${ }^{1}$ Nazik Yener², Arzu Karlı', Gülnar Şensoy'1 \\ ${ }^{1}$ Department of Pediatric Infectious Diseases, Ondokuz Mayis University School of Medicine, Samsun, Turkey \\ ${ }^{2}$ Department of Pediatric Intensive Care Unit, Ondokuz Mayis University School of Medicine, Samsun, Turkey
}

\begin{abstract}
Human metapneumovirus (HMPV) is a newly described virus of Paramyxoviridae family. HMPV can cause respiratory tract infections in patients of all ages but HMPV related most severe diseases are seen in infants, the elderly population, immunocompromised people or those with chronic diseases. In this paper, we present a 6.5 year-old male patient with HMPV related acute respiratory distress syndrome (ARDS) who has no other risk factors excluding obesity for severe HMPV infection.
\end{abstract}

Keywords: Human metapneumovirus, acute respiratory distress syndrome, obesity, child

\section{Introduction}

Respiratory infections are major causes of mortality and morbidity in childhood and viral agents are the main agents responsible. Human Metapneumovirus (HMPV) was first isolated in 2001 from respiratory tracts as a new paramyxovirus (1). HMPV causes a respiratory syncytial virus (RSV) like clinic that causes both upper and lower respiratory tract infection. Although it can cause infection in all groups, studies have shown that mostly children under the age of 5 are affected from HMPV and children under the age of 2 are under risk (2). It can progress more severely in infants, elderly and in patients with a comorbid chronic illness or immunosuppression. There
Özet

İnsan metapnömovirüs (HMPV), Paramiksovirus ailesinden yakın zamanda tanımlanmış bir virüstür. HMPV ilişkili ciddi seyirli hastalıklar daha çok süt çocuklarında, yaşı ı popülasyonda, immünsüpreselerde ya da eşlik eden kronik hastalığı olanlarda görülmektedir. Makalemizde obezite dışında eşlik eden hastalığı olmayan, HMPV'ye bağlı akut respiratuar distres sendromu (ARDS) gelişen altı buçuk yaşındaki erkek olgu sunulmuştur.

Anahtar Kelimeler: İnsan metapnömovirüs, akut respiratuar distres sendromu, obezite, çocuk

is no specific antiviral treatment for HMPV. In literature, there are immunosuppressed cases reported to have been treated with ribavirin and intravenous immunoglobulin (3). This article presents a 6.5 year-old male patient with no comorbid disease other than obesity who developed HMPV related acute respiratory distress syndrome (ARDS).

\section{Case Report}

Six and a half year-old male patient was intubated in a health center he was taken to because of his respiratory distress that developed after his complaints of 2 day long fever, cough and nasal flow and then he was referred to our hospital. The patient was hospitalized in the intensive care 
unit with a diagnosis of pneumonia. His personal history did not show any features other than obesity. His family history revealed that his 4.5 years old brother had a history of recurrent bronchiolitis and a few days ago he had developed respiratory arrest and died at home as a result of sudden respiratory distress that developed after similar complaints. His physical examination showed that his weight was $50 \mathrm{~kg}$ (> 97p), his height was $125 \mathrm{~cm}(90-97 p)$, his body mass index was 32 , his peak heart rate $108 / \mathrm{min}$, his blood pressure was $90 / 60 \mathrm{mmHg}$ and his body temperature was $37.7^{\circ} \mathrm{C}$. His lung auscultation showed obvious thin rales and bilateral rhonchus at the right lung basal. His liver was found $3 \mathrm{~cm}$ palpable. His other examination findings were normal. His laboratory values were as follows: hemoglobin: $10.3 \mathrm{~g} / \mathrm{dL}$, white blood cell count: $14.630 / \mathrm{mm}^{3}$, thrombocyte count: $250.000 / \mathrm{mm}^{3}$, C- reactive protein: $119 \mathrm{mg} / \mathrm{L}$. His blood biochemistry values were normal. His venous blood gas results when he was first admitted were as follows: $\mathrm{pH}: 7.52, \mathrm{PaCO}_{2}: 41, \mathrm{PaO}_{2}: 38, \mathrm{HCO}_{3}$ : 32, BE: $8.9, \mathrm{SaO}_{2}: 83 \%$. Ventilation was started with high PEEP on SIMV (Synchronized Intermittent Mandatory Ventilation) mode of mechanical ventilator [Positive end-expiratory pressure (PEEP) $6 \mathrm{~cm} \mathrm{H}_{2} \mathrm{O}$, peak inspiratory pressure (PIP) 30 $\mathrm{cm} \mathrm{H}_{2} \mathrm{O}, \mathrm{FiO}_{2}$ : 80]. The patient's $\mathrm{PaO}_{2} / \mathrm{FiO}_{2}$ rate was found to be 47.5 (38 mmHg/0.8) and there was bilateral massive alveolar infiltration in his chest radiograph, so he was considered as ARDS (Figure 1). The patient whose oxygenation did not recover despite high PEEP levels was taken to APRV (Airway Pressure Release Ventilation) mode. There was a whole lot of dark secretion in the endotracheal tube. Stained examination from tracheal aspirate showed leukocyte but did not show microorganism. Blood, urine and tracheal aspirate cultures were sent. The patient was started a treatment of cefotaxime, teicoplanin, clarithromycin and oseltamivir. Salbutamol, budesonide, systemic steroid and magnesium sulphate $\left(\mathrm{MgSO}_{4}\right)$ treatment was organized for his bronchospasm. On the first day of his hospitalization, respiratory viral panel (PCR) was sent on nasopharyngeal swab. On the second day, chest radiograph showed significant deterioration (Figure 2).On his third day, dobutamine supplement was started after his echocardiography showed his ejection fraction (EF) to be $57 \%$. His oxygenation recovered and his $\mathrm{FiO}_{2}$ value was decreased gradually. On the seventh day of his hospitalization, the patient was extubated and his control echocardiography on the eleventh day showed that EF had increased to $67 \%$. Thus, dobutamine supplement was stopped and the patient was taken to pediatric infectious disease department from Intensive Care Unit. In the mean time, the patient developed respiratory distress and thus his lung graph was taken. His lung graph revealed obvious infiltration and suspicious air trapping on the right. On the same day, his thorax ultrasonography showed pleural fluid in small quantity on the left hemithorax and consolidated areas with air bronchograms on the lower

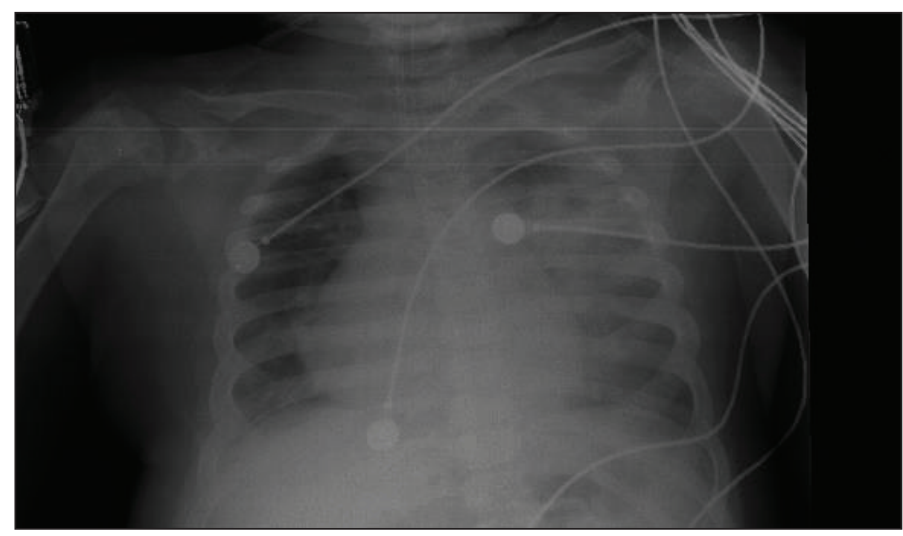

Figure 1. First day chest radiograph showing the infiltration which is more pronounced in the left.

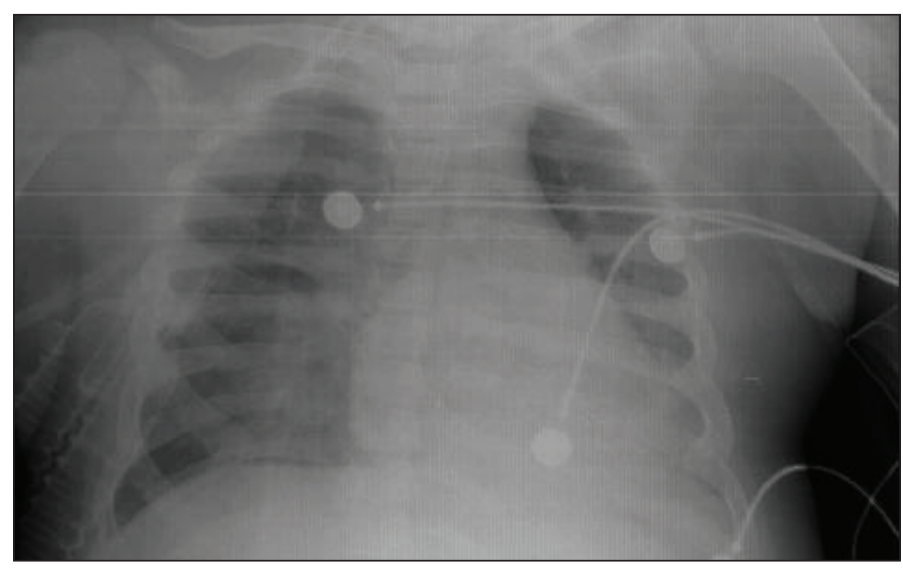

Figure 2. Second day chest radiograph showing thesignificant deterioration.

zone. The patient's cefotaxime treatment was stopped and piperacillin-tazobactam was added with a suspicion of nosocomial pneumonia. Nasopharyngeal swab showed Human Metapneumovirus antigen as positive with PCR and antibiotic treatment was stopped. No reproduction was found in the tracheal aspirate, urine and blood cultures of the patient taken at the first admission to the hospital and during the follow-ups. The patient who no longer needed oxygen and who showed a clinically obvious recovery was discharged on the $25^{\text {th }}$ day of his hospitalization .

\section{Discussion}

Acute respiratory tract infections are the second cause of death among children under 5 years in the whole world (4). Mostly viruses cause childhood respiratory tract infections; however, the agent cannot be detected in a majority of the patients. It has been reported that recently diagnosed HMPV is responsible for $10-15 \%$ of the hospitalizations because of bronchiolitis and pneumonia (4).

HPMV is a RNA virus from paramyxovirus family. It infects directly or by way of droplets as a result of close contact with secretions. It shows seasonal variation and it is confused with 
RSV because of their similar clinical course. Upper respiratory tract infection, bronchiolitis, pneumonia and asthma inflammation are the clinical conditions which are caused most by HPMV.

HMPV-related, severe pneumonia development in children which requires intensive care and respiratory support has been rarely reported (5). HMPV is known to progress more severely in infants, elderly population and in patients with an underlying chronic illness or immunosuppression. Severe HMPV infections have been reported more inimmunosuppressed adults (5). In their study, Williams et al. (6) reported that the rate of HMPV-related hospitalization for children under 5 years was 1,2 in 1000 and that it caused influenza-like respiratory morbidity. Need for intensive care has been seen only in $3 \%$ of the patients.

Another study compared infants with HMPV and RSV coinfection with infants with isolated RSV infection and found that those with coinfection had 10 times increased risk in terms of mechanic ventilation (6).

Majority of children with severe HMPV infection reported in literature has an underlying predisposing situation. Severe HPMV infection which recovered by ECMO (Extracorporeal membrane oxygenation) was reported in a 17 month-old female patient who was receiving chemotherapy because of leukemia, a case who had a prematurity and chronic lung disease that required long term mechanical ventilator support and another child who had immunosuppression because of his liver transplantation (7-9).

Varman et al. (10) reported that severe pneumonia that required HMPV-related mechanical ventilation developed in a 2.5 year-old female patient who had Arnold Chiari malformation, ventriculoperitoneal shunt and cardiopathy and recovery was made through inhaled nitric oxide.

Schlapbach et al. (5) reported HMPV-related ARDS in a 20 month-old male patient who had retarded development and who came to hospital with bronchiolitis like clinical manifestation. They also stated that in the patient who was lost despite ECMO support, underlying neurodevelopmental defect could be a risk factor in terms of severe respiratory illness.

The patient in this study came to hospital in January when viral respiratory tract infections are most commonly seen with a complaint of respiratory distress and ARDS manifestation. He did not have a history of underlying chronic disease except obesity or immunosuppression. Since obesity is known to be a risk factor in severe influenza infections, nasopharyngeal sample was sent to detect respiratory virus antigens considering that the patient might have influenza pneumonia; however, HMPV was found to be positive. This result made us consider that obesity may be a facilitating risk factor in severe HMPV infections. No studies were found in literature on obesity being a facilitating factor or not. It was thought that our patient's brother who developed respiratory arrest at home because of similar complaints could have positive HMPV and inflammation in asthma may have caused respiratory distress.

As a conclusion, recently diagnosed HMPV can progress severely in people who have predisposing factors and can cause ARDS. Apart from known risk factors such as prematurity, chronic disease and immunosuppression, obesity can also be a predisposing factor. Further studies are needed to understand how much obesity increased the risk of severe HMPV infection.

Informed Consent: Written informed consent was not received due to the retrospective nature of this study.

Peer-review: Externally peer-reviewed.

Author Contributions: Concept - GA, NB; Design - GA, NB; Supervision - NB, GŞ; Data Collection and/or Processing - GA, AK; Analysis and/or Interpretation - NY, GŞ; Literature Review - GA, AK; Writing - GA, NB; Critical Review - NY, GŞ

Conflict of Interest: No conflict of interest was declared by the authors.

Financial Disclosure: The authors declared that this study has received no financial support.

\section{References}

1. Van den Hoogen BG, de Jong JC, Groen J, et al. A newly discovered human pneumovirüs isolated from young children with respiratory tract disease. Nat Med 2001;7:719-24. [CrossRef]

2. Van den Hoogen BG, Van Doornum GJJ, Fockness JC, et al. Prevelance and clinical symptoms of human metapneumovirüs (HMPV) in hospitalized patients. J Infect Dis 2003;188:1571-7.[CrossRef]

3. Kitanovski L, Kopriva S, Pokorn $M$, et al. Treatment of severe human metapneumovirüs pneumonia in an immuncompromised child with oral ribavirin and IVIG. J Pediatr Hematol Oncol 2013;35:e311-3. [CrossRef]

4. Papenburg J, Hamelin MÈ, Ouhoummane $N$, et al. Comparison of risk factors for human metapneumovirus and respiratory syncytial virus disease severity in young children. JInfect Dis 2012;206:178-89. [CrossRef]

5. Schlapbach $L$, Agyeman $P$, Hutter D, et al. Human metapneumovirus infection as an emerging pathogen causing acute respiratory distress syndrome. J Infect Dis 2011;203:294-5. [CrossRef]

6. Williams JV, Edwards KM, Weinberg GA, et al. Population-based incidence of human metapneumovirüs infection among hospitalized children. J Infect Dis 2010;201:1890-8. [CrossRef]

7. Pelletier $G$, Dery $P$, Abed $Y$, Boivin $G$. Respiratory tract reinfections by the new human metapneumovirüs in an immuncompromised child. Emerg Infect Dis 2002;8:976-8. [CrossRef]

8. Evashuk KM, Forgie SE, Gilmour S, et al. Respiraory failure associated with human metapneumovirüs infection in an infant posthepatic transplant. Am J Transplant 2008;8:1567-9.[CrossRef]

9. Ulloa-Gutierrez $R$, Skippen P, Synnes $A$, et al. Life-threatening human metapneumovirüs pneumonia requiring extracorporeal membrane oxygenation in a preterm infant. Pediatrics 2004;114:e517-9. [CrossRef]

10. Varman $M$, Truemper EJ, Chatterjee A Severe human metapneumovirus pneumonia in a child with chronic illness. Clin Pediatr (Phila) 2010;49:1075-7. [CrossRef] 